Volume 29, 2019

http://journals.sfu.ca/cjsdw

Article

\title{
Social Media Storytelling: Using Blogs and Twitter to Create a Community of Practice for Writing Scholarship
}

Kim M. Mitchell

Red River College

\section{Abstract}

This paper argues that social media can function as an informal community of practice in writing scholarship where knowledge is absorbed into a user's identity and practice through storytelling. Social media has increasingly attracted academics and educators as a method of trialing new research ideas and classroom strategies, seeking early peer review, and as a knowledge translation strategy for sharing research findings. Platforms such as Twitter and blogs work in tandem to provide exposure, encourage reflection, and build community. Storytelling becomes a form of persuasion, through use of literary strategies, to influence change. This argument recognizes how social media writing is situated in a unique genre and requires writing strategies that may be unfamiliar to academic writers. A social media storytelling interlude demonstrates a case of social media persona development for writing scholarship and acts as an example of the voice, tone, and literary strategies of social media writing. The paper concludes with a discussion of strategies aligned with researching the impact of social media on pedagogical practices.

\section{Introduction}

If we want a different future, we need to tell a different story (King, 2003).

The story behind this paper begins with my discomfort with the concept of knowledge translationmobilization, transfer, dissemination-call it what you may depending on your discipline and your mood. I am a nurse by discipline, a nurse educator by employment, and a writing scholar through a 
Volume 29, 2019

http://journals.sfu.ca/cjsdw

combination of default and passion. The phrase knowledge translation, most commonly used in health research, refers to moving formal research findings into a practice environment thereby evoking change in practice. But how does knowledge translation work in educational research, and more specifically, writing scholarship, where everything we do in the classroom is steeped in contextual and relational issues? What does pedagogical knowledge transfer mean within a context where we are more likely to wander down the hall and talk to an experienced colleague than open up a library database and search for published research to solve our problem? What does it mean in a context where much of what we do as educators involves "standing in data" on a daily basis with our students and mentees-data which is difficult to quantify or collect given ethical restrictions for researching our own students but yet is rich lived experience? (Chanock \& Vardi, 2005).

In work on narrative inquiry that is situated in the internet era but predates the explosion of social media, Clandinin and Connelly (2000), incorporating the ideas of John Dewy, identify:

The notion of experiences grow out of other experiences, and experiences lead to further experiences ... We learned to move back and forth between the personal and the social, simultaneously thinking about the past, present, and future, and to do so in ever-expanding social milieus. (pp. 2-3)

Every decision we make in the classroom and with writers is dependent on a previous decision, and that decision influences future decisions (Huber, Cain, Huber, \& Steeves, 2013). How do we learn and grow from our daily decision-making in the classroom and one-on-one with student writers? If knowledge is built through these informal, contextual mechanisms, how do we know if it is the kind of knowledge that will shape effective pedagogy and change our students' learning for the better? Our social milieus have expanded and created a need to understand what role digital venues for storytelling, such as social media and blogs, may have in helping researchers and educators understand the benefits of constructionist knowledge translation strategies: how can social media facilitate this process?

There has been growing interest in the literature exploring the mechanism by which social media promotes research, the development of experiential knowledge, and the social change that is often required to integrate research knowledge into practice. From constructionist perspectives on learning, it is believed that not all knowledge comes from research. Often the knowledge most valued is tacit and experiential (Gabbay \& le May, 2004; Greenhalgh \& Wieringa, 2011; Rieger \& Schultz, 2014; Wieringa \& Greenhalgh, 2015). The researcher is also often the educator and seeks answers to research questions which emerge from their experience. In this context, there is an acknowledged 
Volume 29, 2019

http://journals.sfu.ca/cjsdw

inseparability of the researcher, the participant, and the educator (Clandinin \& Connelly, 2000). The artificial lines drawn between the world of education practice and the world of research are blurred. Social media can amplify findings of formal research so they have the potential to enter the practice arena more quickly, but it can also promote change in practice through discussions of experiential knowledge.

All academic disciplines use writing as a pedagogical strategy. Writing is also the key strategy expected in research dissemination activities. However, different disciplines value different writing genres and conventions, which means there are many forms of writing knowledge that could benefit the academic community as a whole, if that knowledge had a path to cross disciplinary boundaries. Given that knowledge sharing is often constrained by these disciplinary boundaries, social media may hold the potential to open up those boundaries (Salter \& Kothari, 2016). Sharing and community building in social media has the potential to facilitate understanding and change beliefs with respect to how writing instruction can improve the writing outcomes of our students in our classrooms and enhance the value of the role writing plays in knowledge building in the academy.

Writing pedagogy, due to its disciplinary structure, is not exclusive to academics who have dedicated their careers to writing scholarship. Writing is, therefore, assigned and taught by content experts who may or may not write themselves, and who may or may not have access to the expertise of a writing scholar. Thus, many myths of what constitutes effective writing and instruction continue to persist in academic communities (Ball \& Loewe, 2017). As writing scholars, we recognize the lifelong journey to writing expertise but many academics are thrown into implementing and evaluating their own writing pedagogies without formal instruction as to how to proceed and with limited time to reflect on the success of their methods. The educational changes that scholars are motivated to make are often associated with belief systems and attitudes which are influenced by personal experience and contextual complexities more so than by prescribed research findings (Anfara \& Angelle, 2008; Connelly \& Clandinin, 1990; Veletsianos \& Kimmons, 2012). When problems need to be solved, in both practice and life, a person's first source of knowledge is sought through seeking out a more senior member of their community. The problem is related and the response received often comes in the form of a story (Chanock, 2014; Christiansen, 2011; Huber et al., 2013).

When attempting to incorporate principles of knowledge translation into education research and writing research, we must consider that the common usage of the word "translate" involves the rendering of one language to another language. The metaphor of translation of research involves the movement of research from one world, the world of science, theory, and the academy, to the world 
Volume 29, 2019

http://journals.sfu.ca/cjsdw

of practice and the public - two contexts which effectively speak different languages (Van de Ven \& Johnston, 2006). Translation is a form of interpretation. Interpretation of knowledge within a community involves a complex web of experiential practice, identity formation, and is negotiated. Many of the challenges inherent in integrating formal research into practice domains is due to the decontextualization of research findings which lack the human, relational, and aesthetic qualities present in the practice environment (Salter \& Kothari, 2016). Negotiated meaning (Lave \& Wenger, 1991; Salter \& Kothari, 2016; Tusting, 2005; Wenger, 1998) implies that researchers and relevant stakeholders seek partnerships in knowledge sharing and learning to solve contextual problems. How the problem is defined, delimited, and addressed is negotiated within a community. Sometimes that negotiation involves exploring formal research and sometimes it involves lived experience and intuition.

Social media use through platforms such as Twitter and blogs, can act as a form of storytelling through the development of an online persona and a complex blending of the personal and the professional (Barnes, 2017; Lupton, 2014; Thompson, 2016). Social media strategies have been increasingly connected to Lave and Wenger's (1991) situated learning theory and communities of practice (Byington, 2011; Rolls, Hansen, Jackson, \& Elliott, 2016; Thoma et al., 2017; Woods, Cashin, \& Stockhausen, 2016). Research and the translation of findings to practice could benefit from understanding the cultural shift to technological forms of sharing and how they apply to research dissemination. The use of story in these venues could emerge as a legitimate research product which functions as a method to facilitate understanding, reflection, and, ultimately, change in outdated practices and policies by inviting collaboration with ideas among diverse community members (Barnes, 2017; Gallagher, 2011; Koch, 1998). This paper will explore the role of social media in building a community of practice through storytelling and through the community known as Academic Twitter in tandem with research blogs designed to share experiential knowledge. A case exemplar, in the form of a personal narrative, exploring the knowledge area of writing scholarship will be used to demonstrate the role of combining the two social media platforms for these purposes. Finally, since the research exploring the effectiveness of social media for research and knowledge sharing is limited, a discussion of the various research approaches that may be taken in order to evaluate this process will be discussed. 
Volume 29, 2019

http://journals.sfu.ca/cjsdw

\section{Storytelling in Social Media Communities of Practice}

"The truth about stories," says Thomas King (2003), "is that that's all we are" (p. 2). Most of human life is experienced through story (Fairbairn \& Carson, 2002). Storytelling builds community through meaning making and employing literary elements that create engagement and connection, thereby holding the attention of the audience (Coulter \& Smith, 2009; Huber et al., 2013; Koch, 1998). Stories are the "smallest unity by which human beings communicate their experience and knowledge of the world" (Haigh \& Hardy, 2011, 408). By telling stories we demonstrate a fundamental understanding of who we are, where we have come from, and where we are going (Connelly \& Clandinan, 1990; Huber et al., 2013). Great stories are audience driven and demonstrate an understanding of the community for which they are told (Haigh \& Hardy, 2011; King, 2003; Koch, 1998). Stories are driven by a need to persuade. They are, in the words of Klein, Connell, and Meyer (2007), a form of "narrative engineering." They are constructed, transcend boundaries, and are a possible vehicle for a critical voice disguised with human qualities to promote empathy (Gallagher, 2011). They are metaphorical and poetic and aren't to be taken literally. Stories need to be open to multiple interpretations because interpretation is imperative to absorb a story into a specific context. They explain, encourage discussion, and are validating forces that are to be given away selectively, carefully, and exactly at the right moment for maximum effect (Huber et al., 2013; Lave \& Wenger, 1991).

Stories, or shared narratives, become an integral part of learning within knowledge communities. Stories are a way of knowing (Coulter \& Smith, 2009). The literature discussing storytelling motifs in communities of practice has been adopted in disciplines such as education (Chanock, 2014; Chanock \& Vardi, 2005; Clandinin \& Connolly, 2000; Connelly \& Clandinin, 1990; Gallagher, 2011; Huber et al., 2013), nursing (Christiansen, 2011; Fairbairn \& Carson, 2002; Haigh \& Hardy, 2011; Koch, 1998), medicine (Charon, 2006), and business (Klein et al., 2007; Vickers, 2010). To define storytelling, Christensen (2012) begins her description of her journey to tell the stories of her Indigenous participants living through homelessness by stating, "At its heart, research is storytelling" (p. 232). Haigh and Hardy (2011) define storytelling as, "the effort to communicate events using words (prose or poetry), images, and sounds often including improvisation or embellishment" (p. 408). On the surface, the idea of using story to share research findings may seem incompatible with the linear way of thinking valued by the academy and especially more objectivist forms of research (Gallagher, 2011). However, Coulter and Smith (2009) argue that even quantitative researchers spin their work with selective "additions and subtractions" seldom giving enough detail for replication. Those 
Volume 29, 2019

http://journals.sfu.ca/cjsdw

quantitative research findings contain a story that is steeped in experience from the point of inspiration, the struggles of data collection and implementation, and in the interpretation of the findings where "the backstage talk [can be] ... rife with politics, negotiation, and chaos" (Chanock, 2014, p. A-126) all of which can be explained in a Twitter thread or a blog post but are unlikely to appear in a scholarly publication.

The use of storytelling through blogs and social media to relate experiences that may be difficult to explore through formal research, solves a fundamental problem in educational contexts where we are "standing in data," as Chanock and Vardi (2005) identify in their writing center environment. These authors relate the paradoxical reality of how, because of the devalued nature of experiential data, researchers can cite published accounts of teaching experience and not be criticized, but it would be labeled anecdotal to tell their own teaching stories relating the same information in their academic papers. These stories of lived experience are difficult to capture in formal research for two fundamental reasons. First, because it is difficult to gain ethical approval to research your own students in the context of your direct work with them, and second, because to relate another individual's story risks their identification.

The solution to the risk of identifying a "character" in an educational story told in a blog is through euphemizing, changing details, or combining two or more stories into one story, a process Coulter and Smith (2009) say in literary circles is often called fictionalizing, reworking, or crafting. In the world of social media, fictionalizing is a necessary convention for knowledge sharing. The word "story" conjures images of created fictions, yet the relationship between truth and fiction is symbiotic. Vickers (2010) calls storytelling, "a lie that can help us see the truth" (p. 561). It is possible for fiction to contain truths and for factual accounts to contain fictions that are not necessarily declared to be as such.

This fictionalization process or in the words of Connelly and Clandinin (1990), "narrative smoothing," is standard and understood in social media and blogging: writing to hide the identifying characteristics of their context to share a lesson learned, and present a problem solved or strategy implemented successfully (Chanock, 2014). In these circumstances, where being too specific about a particular individual or context could be hurtful or damaging, social media writing can employ narrative smoothing to tell a story by importing fragments of the real story, maintaining its essential truth and lesson, but the individuals who inspired the story remain anonymous (Chanock, 2014). These stories are created but remain rooted in a fundamental truth. Knowledge is constructed through merging relevant aspects of multiple stories, multiple voices, and the social context (Coulter 
Volume 29, 2019

http://journals.sfu.ca/cjsdw

\& Smith, 2009). But stories don't always need to be fictionalized to achieve knowledge transfer, as Thompson (2016) observes. Social media can be a place to share those conversations that take place in hallways and classrooms, as a mechanism to collect raw ideas into more formalized thought. Some of these ideas may not be ready for academic publication but still beg discussion (Saunders et al., 2017).

In situated learning that takes place in communities of practice, participation is a constant negotiation between understanding and experience (Lave \& Wenger, 1991). Storytelling can become a motif for bridging the dichotomy between understanding and experience in learning situations. One of the exemplar case studies Lave and Wenger used to facilitate the description of a community of practice was the exploration of membership in Alcoholics Anonymous (AA) where storytelling is actively used to facilitate the transition of an identity as an alcoholic into the identity of a nondrinking alcoholic. Old timer AA members tell their personal stories of alcoholism as a model for the newcomers who can recognize themselves and their experiences in those stories. Newcomers then learn to tell their own stories through exposure to the stories of veteran members. The way the stories are told is not taught. Stories of alcoholism are built as, around the circle, each member tells a piece of their own story, which, through resonance and relatability, triggers the next storyteller who builds upon the words said and tells their story as it relates to the previous story.

A similar process functions on social media. A Twitter user may start with their own story which can trigger other twitter users to add their contribution to that story through retweeting or through replying to the original Twitter user. The short context-free quippy stories on Twitter can stimulate a variety of responses that may or may not fit the context sitting behind the original tweet. The interpretation of the tweet, now in the hands of the audience, matters little if the goal is to inspire and stimulate reflection in other scholars. Academic Twitter is a mix of novice and experienced scholars, and the social levelling that occurs on the platform makes it the great equalizer (Lupton, 2014). In this way, knowledge can be built and will contribute to the identity of the virtual novice scholar through reflection on the issue and reflection on their own practices as researchers and educators (Stewart, 2015; 2017; Thompson, 2016). Reflection on practice can contribute to decisions to experiment with a new practice in their research or with their students. Stories told in this fashion have the power to bind the storyteller and the receiver together which acts as ancentive for learning and action. Those interacting with a tweet must translate the lesson from tweet to fit the context of their own classroom or assignment. The emotional and reflective engagement that occurs 
Volume 29, 2019

http://journals.sfu.ca/cjsdw

in this process can transform how the audience of a story views themselves, others, and their practice (Christianson, 2011).

\section{Social Media Writing: A Genre Unto Itself}

In social media writing, a sense of timing is mandatory for success. Literary elements can be employed, plot constructed, scenes set, characters described, narrator positioning established, conflicts introduced, and resolution proposed (Clandinin \& Connelly, 2000; Coulter \& Smith, 2009). Interpretive integration emerges from professional experience and personal reaction. Knowledge sharing begins by trialing ideas through "tweets," 280 character "soundbites" on a subject of interest to the tweeter, which may be expanded on in a blog, which functions to test out ideas prior to a formal academic publication. Following publication, an academic paper can again be shared and discussed within the online networked community of practice.

Tweets, or microblogs, constitute a genre of writing which is more personable than the voice used in academic contexts, which enhances the relatability factor of the message being sent (Stewart, 2016). Twitter users report that the best twitter accounts to follow tend to have a distinctive voice which varies with content, employs humorous conventions, and integrates the personal and the professional into a unique identity (Lupton, 2014). Alternatively, long form blogs can be written in many formats and for many reasons. While some blogs do tend to adopt a similar formal tone like a peer reviewed paper, many blogs take a more casual voice than an academic paper (Mewburn \& Thompson, 2013; 2017; Thompson, 2016). Blogs can also be written to mimic the tone and voice present in journalism or a diary. Some blogs are used as curation sites to collect lists, catalogues, web links, and other resources so they are available for easy retrieval (Thompson, 2016). Twitter and blogs are a place you can mold your writing and make the most of imitation, manipulate pop culture, or emulate your heroes.

The merging of storytelling and research has origins in the narrative inquiry tradition of qualitative research. Social media stories can be told using either an oral (podcast), written (Twitter, blogs) or combined (digital stories) tradition. Language and its use as a persuasive strategy to build community and contribute to the reach of knowledge requires consideration (Tusting, 2005). Choice of language acts as a signal of membership in a community of practice (Lave \& Wenger, 1991). Academics rarely receive training in modes of writing including training in traditional academic writing, to the point that many academics are reticent to identify as "writers" (Christensen, 2012; Thompson, 2016). Yet much of the construction of an academic identity occurs through writing and 
Volume 29, 2019

http://journals.sfu.ca/cjsdw

in the world of social media, writing ability is critical in developing an identity and status in virtual networks (Mewburn \& Thompson, 2017). Stewart (2017) who draws from Ong's theory of secondary orality, observed that long-term engagement in Twitter favors “ 'fluency, fulsomeness, and volubility' [Ong's words] of highly-skilled oral performances" (p. 12). Playfulness, rhythmic patterns, repetition, alliteration, and formulaic familiar expressions are successful tweet strategies (Stewart, 2016). Artful repetition becomes the convention of successful social media writing and persuasive capabilities.

The caution is that not all academics can transfer the writing skills they have honed during formal dissemination of their work through peer reviewed publications into the kind of writing required to capitalize on the persuasive capacities required in collaborative knowledge sharing via networked participation (Teirney, 2002). The type of writing required to produce a successful social media knowledge translation strategy is methodological writing. Acute awareness of the moment to moment audience for your work must be attended to (Richardson \& St. Pierre, 2005). The ability to codeswitch, or alter the voice of a communicative text based on target audience is a critical skill (Stewart, 2017). Texts with the objective of social, behavior or attitudinal change need to inspire something beyond itself. They become in this perspective, as Vickers (2010) states, "voyages of creation and discovery" (p. 562). They need to move thinking, emotions, and relationships (Richardson \& Lockeridge, 1998).

Writing in fiction is most effective when authors choose to show, rather than tell, in the weaving of a narrative. Social media storytelling can benefit from the same strategy. By virtue of this old adage, I now present a storytelling interlude where I will demonstrate many of the social media writing strategies mentioned in the previous two sections. I will, to give a few examples, share experiential knowledge, tell the backstage politics of a pedagogical situation without risking identities, talk about persona creation, and emulate my heroes.

\section{Interlude: A Twitter Story}

Wait a minute while I clear my throat. It will help me to change my voice.

This story begins with me trying to tell another story in a way that doesn't throw a colleague under a bus. Even though she was wrong, she doesn't deserve to be hung for her mistake. She made a mistake we all make when we are first starting to teach. Her story, which ended up intersecting with my story, is a story about harsh grading, a student uprising, and I, the so-called writing expert, getting called in to fix it. The topic of the assignment could have been pathophysiology, gerontology, pharmacology, palliative care, or maternity. It makes no difference. I made, what is sometimes a 
Volume 29, 2019

http://journals.sfu.ca/cjsdw

controversial decision in academia, to support the students and not the teacher. We can have our colleagues backs to a point, but when our colleagues are wrong and it hurts students it stops there. This story is also a story about the "knowledge effect" - that subconscious belief we have that all our knowledge is shared by others. ${ }^{1}$ That all our knowledge is common knowledge. Which is fine, until it isn't. Which is fine, until you grade student writing content expecting undergrads to know exactly what you know, including having your advanced experience and intuition. They won't. They use what language and knowledge of our discourse they have in the moment. It is hard when you're learning to teach and evaluate student writing to know where the line is between what they should know and what you know. We also know what is normal in our discipline for language choices. They may not but like all new language learners, some of them will pick it up faster than others.

Anyway, back to trying not to throw my colleague under a bus. I wrote a blog. I posted the blog. I shared it on Twitter to the four followers I had at the time and then less than an hour later, serendipitously, or via some Twitter cyber glitch, someone from my department followed my anonymous account. I had fictionalized the story to the best of my ability but I feared it was not enough for it to be unrecognizable to someone who knew the context, the characters involved, the incident I hoped we could all learn from: that we can't grade students with the expectation that they will command the same understanding of nursing language and nursing knowledge that we have. So, I deleted the tweets with the blog link. I set the blog post setting to private and that is the state the blog with the story of the student uprising remains at to this day, nearly three years later. Hidden. But I wrote a tweet about a year and half later, this time to 4000 followers, suggesting that it is OK for our students to sometimes say things differently than we would say them. That's how they learn as they play with our language. It remains my most popular tweet to date. ${ }^{2}$

I wrote about writing voice instead. I was inspired by a passage I read in an article ${ }^{3}$ had printed two years before but was just now, on summer break, pulling out to read. It said in nursing we are trained to privilege those authors that walk before us rather than our own voices-like something couldn't be said unless someone more senior to us had said it first. It was an article about doctoral student writing. This is why I read it, because in about a month, I would officially be a doctoral student and it inspired me to want to talk about writing with my own voice. I had done that in my past life as a young adult fiction writer, why not as an academic writer? That young adult voice I cultivated behind closed doors and under bed covers in my teen years-a hybrid voice of old soul wisdom and immature arrogant misanthropist—has been useful to my tweeting. My first Twitter bio tag line when I started my account and my blog was, "Let's talk about academic writing without the academic voice." 
Volume 29, 2019

http://journals.sfu.ca/cjsdw

I wanted to talk about writing, its frustrations and elations, its profoundness and its ridiculousness. I wanted to be colloquial about it.

That voice blog evolved into a class assignment, and the class assignment evolved into a published paper. ${ }^{4}$ That story has a happy ending.

I developed the AcademicsWrite (@academicswrite) Twitter account to talk about my research, my doctoral student life, my teaching life, and share my experiential knowledge. I started off anonymous because I was scared I would fail. I was scared I would be found out an imposter. I was a career educator, writing instructor, and registered nurse-a strange and wonderful combination which has brought me many privileges in this academic world in a discipline that doesn't talk much about its writing. I've called myself a strange combination of seasoned academic and early career researcher. AcademicsWrite is a persona-a character I created for which I was the narrator. She isn't me. She isn't not me. I try to be human but not personal. Personal doesn't work when your avatar is a Red Door. Your followers expect you to stay in character. My character tweets about writing. I focus on inspiring. I'm not a writing tipster; I don't believe any of my tips will work for you, because my audience already knows how to write. They just need to learn to feel good about that. I aim to reflect back at you your own emotional reality while you face the blank page-while you suffer the angst you feel about the shitty paragraph you just wrote. Those are the tweets that work for AcademicsWrite. Quirky observations about muses, the incoherent writing of philosophers, the writing problems you solve standing naked in the shower, and my not-so-secret desire to drop a fourletter word in an academic publication. ${ }^{5}$

I write blogs that often start with tweets or tweet threads. ${ }^{6}$ I wrote a blog about how writing is devalued and a blog about writing myths. I wrote a blog about storytelling and research while I prepped to write this paper. The writing myths blog prompted someone to share with me a source ${ }^{7}$ that makes me think I may never need to write another thing about writing again. My mission is over. My work is done here. Someone else wrote a comment that told me that no one believed these myths anyhow, and he was right. No writing scholar believes these myths, but I witness these myths alive and festering among my non-writing scholar colleagues. Writing scholars already know that teaching grammar does not improve writing; that discourse struggles are perceived as grammar mistakes; that successfully writing in one course or one discipline doesn't mean they will successfully pull off my assignment without guidance; and that sometimes our students writing problems are simply because they can't read our language. Sometimes when community building it will seem like we preach to the choir. But that's OK. Preaching to the choir is what keeps them singing. ${ }^{8}$ But I know I 
Volume 29, 2019

http://journals.sfu.ca/cjsdw

will have done my job if one subject matter expert goes back into their classroom having reflected on the reality that if they assign writing, whether they like it or not, they are the writing instructor.

I attempt to change practice but my community changes my practice too. I have developed a greater sensitivity to my students' complicated lives, I'm learning how the experiences of scholars of colour or LGBT status are different than mine as a white woman, I've confirmed what I've always believed-that learning styles are bunk, and I've had some moments of serious contemplation about the relevance of "handing out" grades.

This is my Twitter story. Or a part of it anyhow. In the tradition of Thomas King, ${ }^{9}$ dear readers, I leave you with this final thought before I abandon this voice for the other. You've heard about the knowledge effect and seen writing voice demonstrated. Take that knowledge and do with it what you will. Lie awake in bed at night and think about it, talk about it in the staff room, mimic it in your own writing, tweets, or blogs. Ignore it. But don't say in the years to come that you would have been a better educator if only you had heard this story. You've heard it now.

\section{Using Formal Research to Evaluate the Impact of Storytelling in Social Media}

Storytelling through social media can become the catalyst for change in attitudes, beliefs, and practice, however research into how storytelling affects change is scarce. Stories are not the outcomes of change but the origin of that change in this perspective. Learning occurs because assumptions are challenged and values and beliefs are tested (Clandinin \& Connelly, 2000). It serves to form relationships between distant others, with that distance produced through geography and disciplinarity, but creates a collective reflective voice. But in the world of the academy it is a necessary obligation to establish how to evaluate if that social change is taking effect.

Both Twitter and blogging platforms have built-in metric systems to assist with our own selfevaluation of our social media reach, however communities of practice, situated learning, and storytelling are constructionist methods of creating research impact and social change. Constructionist methods of knowledge translation recognize that metrics and objective evidence are only providing a partial story. Nevertheless, in a world of science and grant funding bodies that continue to value countable and visible methods that change is occurring, measures cannot be completely ignored. Social media has numerous built in mechanisms for metrics that can work in tandem with metric systems aligned with many journal publications (e.g. Altmetrics). Case study 
Volume 29, 2019

http://journals.sfu.ca/cjsdw

research exploring the differences in exposure received when comparing articles posted or not posted on social media terms of number of abstract reads and full article downloads, found articles shared on social media were significantly more likely to be downloaded (Thoma et al., 2017). These authors also identified that counts of articles viewed nearly tripled if the social media post was accompanied by an infographic and were five times greater than standard promotion (sharing of a link to the article alone) if a podcast was created as part of the promotional strategy and shared along with the article. Buckarma et al. (2016) found a similar increase in article views if a blog post was written to promote a study.

The metrics tools available on both Twitter and blogging platforms are useful for collating and counting views of pages, appearances of tweets, "likes," and retweets, but provide very little evidence for how scholars make sense of each other and of the work they share and who they choose to follow in online environments (Stewart, 2015). Metrics can appear significant but a click on a link does not mean the link was read. A download does not guarantee that the article will be cited in a future publication. These are the metrics most valued in the world of the academy and contribute the highest consideration in tenure and promotion conversations. Reach does not equate with impact. Metric studies explored for this discussion also neglect to acknowledge the power of following on the production of impressive metrics achieved through social media sharing. Sharing a post on Twitter will have little reach if the account doing the sharing has a small following or if the only tweet action from an account is to share their own work in a robotic impersonal voice. Followings are created through engagement, development of a persona, and development of an ongoing never-ending story of connected postings which takes time and thoughtfulness. Blogs that are only written sporadically will not have the same sense of travel that blogs with multiple contributors, multiple posts per week, written by a social media user who has garnered a reputation as trustworthy (Saunders et al., 2017) or who has a "Twitter personality" (Stewart, 2015).

In her qualitative interviews exploring academic influence on the Twitter platform, the participants in Stewart's (2015) analysis had an ambiguous relationship with metrics. They mattered, but perhaps not as much as one might imagine when it came to making decisions to follow another user. Nevertheless, the Twitter users interviewed alluded to the importance of reputation when assessing Twitter metrics. Users were more likely to retweet content from accounts with high followings. Habituated, timely engagement, corresponded with increased visibility, reputation, audience, and reach (Stewart, 2016). However, one of the most cited reasons that academics give for not using social media is the time commitment required to build that following and reach (Saunders, 
Volume 29, 2019

http://journals.sfu.ca/cjsdw

et al. 2017; Stewart, 2015), because it was rare for academic credit to be given to researchers who chose to dedicate time to social media activities (Thompson, 2016; Stewart, 2017). Time given to social media did not result in a corresponding increase in their institutional reputation. In many cases, Stewart's (2015) participants had a greater reputation and power on Twitter than they felt they had in their own institutions which at times created conflict in their face-to-face worlds where senior colleagues perceived their networked engagement as illegitimate, or a sign of "not knowing your place" (p. 301). However, it is possible to leverage social media power and influence in cases of tenure and promotion as a blog with social media reach is an indication that a scholar has a voice in the academy. Examples of blogs and the comments that are associated with them can be provided in tenure applications as examples of the power and influence associated with networked scholarship. Social media is a place that relationships are built and letters of recommendation can be requested from key followers as evidence that influence and reputations are having an effect.

Nevertheless, in preparation to write this paper, I observed a large gap exists in research literature to assist with answering the question, how are social media users influenced to change their classroom practices based on their social media engagement? Stewart's $(2015 ; 2016$; 2017) qualitative doctoral work begins to get at this question of academics' lived experience of social media in terms of benefits and pitfalls. Additionally, the kinds of knowledge academics share in blogs in discipline areas such as writing scholarship is unclear. Several research approaches may contribute to answering these questions including qualitative investigations exploring the lived experience of academics on social media; the effectiveness of fictionalization methods for sharing stories from the classroom; use of digital storytelling; and analysis and synthesis of blog content within a research domain.

\section{Qualitative Investigations With Social Media Users}

The question of how scholars engaged in social media transpose their online interactions into actions in the classroom to benefit students and learning has not been addressed through formal research. Qualitative methods would be the most effective approach for hearing the stories of educators and the influence their social media activities have on their classroom practices. Volunteers could be sought from a Twitter community which would allow for a possible international and interdisciplinary perspective. Alternatively, Tweets and blogs could be collected which described how change occurred due to social engagement or how research uptake was achieved in practice. If stories of pedagogical change are sought, an appropriate methodology must be chosen for addressing 
Volume 29, 2019

http://journals.sfu.ca/cjsdw

the research question. Both narrative inquiry (Chanock, 2014; Connelly \& Clandinin, 1990; Clandinin \& Connelly, 2000; Huber et al., 2013; Sandelowski, 1991) and ethonography (Richardson, 2002; Richardson \& Lockeridge, 1998) have been cited as having a close relationship to storytelling and are more welcoming to uses of alternative narratives employing literary strategies for representing participant experiences with a phenomenon. Autobiographical and personal narratives, perhaps in the form of autoethnography, may also be appropriate approaches (Richardson, 2002; Sandelowski, 1991). My social media story interlude, related above, is an example of a personal narrative.

\section{Fictionalization Methods}

Qualitative researchers have experimented with creating fictional accounts of their research findings to tell a collective truth, protect the identities of individual participants, or create a metaphor that supplies a life lesson (e.g. Christensen, 2012; Richardson, 2002; Vickers, 2010). In the same way that journalists began to borrow literary devices from novels to make their factual stories more engaging, researchers can use the same strategies (Denzin, 1996). In educational research, fictionalization can be used to mask identities of characters. Strategies such as creating composite characters can be used to impart lessons learned while interacting with students. Christensen (2012) developed a fictional story of her participants experiencing homelessness which told a first-person narrative of a young homeless woman who was a composite of many participants in her original research. Vickers (2010) used a strategy where she used "fictive imagining" to support the non-fictional story imparted by a participant. She imagined the experience of the husband of that participant even though he had never been a part of the interview process. Imagining the thoughts and feelings of a participant or the characters the participant speaks about in their narrative can build empathy as well as provide an alternative interpreted truth of the context of the participant (Richardson, 2002; Vickers, 2010). Educational and writing researchers can write fictitious narratives which are composites of multiple students or multiple faculty members to tell various stories of interactions in and out of the classroom. Research stories and interviews can be represented as fiction, personal narrative, poems, and plays in this perspective (Gallagher, 2011; Richardson, 2002).

\section{Digital Storytelling Methods}

Digital storytelling is an arts-based approach which asks participants as part of the research process to create a visual narrative using text, images, video and audio. It can be used as an intervention in a quantitative research study in order to evoke change in a variable of interest, as a method of data 
Volume 29, 2019

http://journals.sfu.ca/cjsdw

collection in a qualitative study, and as a knowledge translation strategy in order to share research findings with non-traditional audiences such as students or the public (Rieger et al., 2018). Educational researchers could be asked, in their role as research participants, to create a digital story which tells of their experience of changing their practice as a result of interactions they had on social media. These digital stories can be analyzed for content and features of experience, or they could be left to stand alone and be interpreted by the audience who views them. These digital stories can be publicly archived as learning resources and function as a record of the emotional and reflective experience of teaching (Christiansen, 2011) and writing.

\section{Reviews of Academic and Science Blog Content}

Scholars have written analysis and synthesis articles on various issues that have been reported in the news media, for example, to explore reports about the introduction of the human papillomavirus vaccine in the United States (Gollust, LoRusson, Nagler, \& Fowler, 2016), or to analyze the controversy over the introduction of an American nursing registration exam into the Canadian nursing context (Hall, Lalonde, Kashin, Yoo, \& Moran, 2017). In a similar fashion, blogs on a variety of educational topics could be synthesized to explore practice change or opinions regarding pedagogical approaches. Scholars often write blogs within a network of other blogs, meaning that a blog may be written in response to ideas presented in another scholar's blog or based on a published research study. Saunders et al. (2017) consider blogs to be similar to scientific pre-prints and can therefore make a significant contribution to the discourse of a community. These authors perceive that blogs should be considered legitimate forms of knowledge and suitable for citation in academic publications. However, academic and science blogs are not readily indexed or easy to locate on the web which makes it challenging for those who stumble across blogs in their searches to evaluate the quality and credibility of the identified blog (Batts et al., 2008). Mewburn and Thompson (2013) used an innovative approach to overcome the lack of blog indexing in order to conduct an analysis of the content, writing voice, and audience addressed in academic blogs. Both authors are prolific bloggers themselves and they began to collect their sample by exploring blogs they knew from their Twitter networks, collections of blog listings they were aware of such as the list compiled by the London School of Economics. They used the "blog roll" lists-lists that bloggers add to their own blog sites of blogs they follow-to expand their snowball sample. With concern for quality control, the included blogs had to have an identifiable author who acknowledged their institutional affiliation and credentials. Through using such methods, a wide sampling of blogs can be located to answer the 
Volume 29, 2019

http://journals.sfu.ca/cjsdw

research question which could be targeted to a specific pedagogical strategy (e.g. grading academic writing) or targeted to discussion of practices with writing in a specific discipline.

\section{Conclusion}

Social media, storytelling, and communities of practice as knowledge translation strategies also opens doors to the discussion of the importance of the open nature of the scholarly process which desires the promotion of trustworthy knowledge. Awareness creates dialogue that may not have left the confines of the faculty watercooler if it were not for social media strategies. Storytelling and other literary strategies promote engagement, curiosity, reflection, and relationship. Narratives in social media need to be constructed using language that is familiar to the human world of practice. Borrowing of worldviews, language, metaphors, stories, and theories from other disciplines can contribute to learning and change in educational practice (Clandinin \& Connelly, 2000). Social media is the ideal platform to facilitate interdisciplinary merging of ideas. Blurring disciplinary boundaries will disrupt status quo and tacit practices (Mewburn \& Thompson, 2017).

Social media can act as a form of storytelling which creates an informal community of practice. Through that community of practice, we as scholars can share our experiential knowledge, which in the world of research, scholarship, and academic publication can hold less value than formal research. Thus, there is a disconnect between the formalized world of the academy and what counts as knowledge, and the world of practice which values lived experience as told in the stories of educators and writing scholars who have walked the path ahead of us. Social media and storytelling can provide a bridge between research knowledge and practice knowledge in a reciprocal process. Knowledge built and shared through social media platforms becomes an embodied form of learning where scholars incorporate knowledge into their identity, enact it in practice, and share that knowledge through story in an informal mentorship capacity. An example of how a social media persona and voice, created within the platforms of blogging and Twitter as two examples of social media, was presented in the form of a personal narrative as it pertains to writing scholarship. As a constructionist strategy of knowledge translation, the research strategies required to assess the effectiveness of social media storytelling on practice change are necessarily also housed in in research strategies associated with a socially constructed epistemology. This investigation served to introduce the issues related to social media storytelling and sharing of knowledge, both research and experiential, so it can influence change in writing scholarship practices across disciplines. Further research is required 
Volume 29, 2019

http://journals.sfu.ca/cjsdw

to explore the question of how social media has influenced such practice and pedagogical changes through the conversations that originate on social media platforms.

\section{Endnotes}

1. To maintain the fluency required in effective storytelling, I am forgoing citations during this portion of the paper in favor of end notes. The knowledge effect is discussed in depth in Hayes and Bajzek (2008).

2. The Tweet: "One of the hardest things about grading is resisting editing student sentences to sound like your voice instead of theirs. It's one thing if they've legitimately picked the wrong word but sometimes it is just $\mathrm{OK}$ for them to say things differently than you would." It was my most popular tweet at the time of writing and submitting this paper for publication but isn't any longer. However, the inaccuracy of this statement bothers me not because the rhythm of this sentence still feels good.

3. (Ryan, Walker, Scaia, \& Smith, 2013)

4. (Mitchell, 2017a)

5. Success!!

6. (Mitchell 2017b, 2017c)

7. (Ball and Loewe, 2017)

8. Good storytelling often involves emulating your heroes. Here I am liberally emulating a line, written by Aaron Sorkin, from The West Wing, Season 4, Episode 17, "Red Haven's on Fire."

9. King concludes all his chapters to his book in a similar fashion. For example, chapter 4 concludes with: “Take Louis's story, for instance. It's yours. Do with it what you will. Cry over it. Get angry. Forget it. But don't say in the years to come that you would have lived your life differently if only you had heard this story. You've heard it now" (p. 119). 
Volume 29, 2019

http://journals.sfu.ca/cjsdw

\section{References}

Anfara, V. A., \& Angelle, P. S. (2008). What research says: Communities of practice promote shared learning for organizational success. Middle School Journal, 39(5), 52-58. http://www.jstor.org/stable/23044369

Ball, C. E., \& Loewe, D. M. (Eds.) (2017). Bad ideas about writing. Morgantown, WV: West Virginia University Libraries.

Barnes, N. (2017). Blogging as a method of inquiry. Reconceptualizing Educational Research Methodology, 8(1), 17-26. http://journals.hioa.no/index.php/rerm

Batts, S. A., Anthis, N. J., \& Smith, T. C. (2008). Advancing science through conversations: Bridging the gap between blogs and the academy. PLOS Biology, 6(9), 1837-1841.

Buckarma, E. H., Thiels, C. A., Gas, B. L., Cabrera, D., Bingener-Casey, J., \& Farley, D. R. (2016). Influence of social media on the dissemination of a traditional surgical research article. Journal of Surgical Education, 74(1), 79-83. http://dx.doi.org/10.1016/j.jsurg.2016.06.019

Byington, T. A. (2011). Communities of practice: Using blogs to increase collaboration. Intervention in School and Clinic, 46(5), 280-291. http://dx.doi.org/10.1177/1053451210395384

Chanock, K. (2014). "Telling” insights from experience: Establishing resonance with readers, theory, and participants. Journal of Academic Language and Learning, 8(1), A121-A129

Chanock, K., \& Vardi, I. (2005). Data: We're standing in it! Teaching and Learning Forum. Retrieved from https://clt.curtin.edu.au/events/conferences/tlf/tlf2005/refereed/chanock.html

Charon, R. (2006). The self-telling body. Narrative Inquiry, 16(1), 191-200. http://dx.doi.org/10.1075/ni.16.1.34cha

Christensen, J. (2012). Telling stories: Exploring research storytelling as a meaningful approach to knowledge mobilization with Indigenous research collaborators and diverse audiences in community-based participatory research. The Canadian Geographer, 56(2), 231-242. http://dx.doi.org/10.1111/j.1541-0064.2012.00417.x

Christiansen, A. (2011). Storytelling and professional learning: A phenomenographic study of students' experience of patient digital stories in nurse education. Nurse Education Today, 31, 289-293. http://dx.doi.org/10.1016/j.nedt.2010.10.006

Clandinin, D. J., \& Connelly, F. M. (2000). Narrative inquiry: Experience and story in qualitative research. San Francisco, CA: Jossey-Bass. 
Volume 29, 2019

http://journals.sfu.ca/cjsdw

Connelly, F. M. \& Clandinin, D. J. (1990). Stories of experience and narrative inquiry. Educational Researcher, 19(5), 2-14.

Coulter, C. A., \& Smith, M-L. (2009). Discourse on narrative research: The construction zone: Literary elements in narrative research. Educational Researcher, 38(8), 577-590. http://dx.doi.org/10.3102/0013189X09353787

Denzin, N. K. (1996). The facts and fictions of qualitative inquiry. Qualitative Inquiry, 2(2), 230-241.

Fairbairn, G., \& Carson, A. (2002). Writing about nursing research: A storytelling approach. Nurse Researcher, 10(1), 7-14.

Gabbay, J., \& le May, A. (2004). Evidenced based guidelines or collectively constructed "mindlines?" Ethnographic study of the knowledge management in primary care. British Medical Journal 329, $1-5$

Gallagher, K. M. (2011). In search of a theoretical basis for storytelling in education research: story as method. International Journal of Research and Method in Education, 34(1), 49-61. http://dx.doi.org/10.1080/1743727X.2011.552308

Gollust, S. E., LoRusso, S. M., Nagler, R. H., \& Fowler, E. F. (2016). Understanding the role of the news media in HPV vaccine uptake in the United States: Synthesis and commentary. Human Vaccines \& Immunotherapeutics, 12(6), 1430-1434. https://doi.org/10.1080/21645515.2015.1109169

Greenhalgh, T., \& Wieringa, S. (2011). Is it time to drop the "knowledge translation" metaphor? A critical literature review. Journal of the Royal Society of Medicine, 104, 501-509. http://dx.doi.org/10.1258/jrsm.2011.110285

Haigh, C., \& Hardy, P. (2011). Tell me a story: A conceptual exploration of storytelling in healthcare education. Nurse Education Today, 31, 408-411. http://dx.doi.org/10.1016/j.nedt.2010.08.001

Hall, L. M., Lalonde, M., Kashin, J., Yoo, C., \& Moran, J. (2018). Changing nurse licensing examinations: Media analysis and implications of the Canadian experience. International Nursing Review, 65, 13-23. http://onlinelibrary.wiley.com/store/10.1111/inr.12367/asset/inr12367.pdf

Hayes, J. R., \& Bajzek, D. (2008). Understanding and reducing the knowledge effect: Implications for writers. Written Communication, 25(1), 104-118. http://dx.doi.org/ 10.1177/0741088307311209

Huber, J., Caine, V., Huber, M., \& Steeves, P. (2013). Narrative inquiry as pedagogy in education: The extraordinary potential of living, telling, retelling, and reliving stories of experience. Review of Research in Education, 37, 212-242. http://dx.doi.org/10.3012/0091732X12458885

King, T. (2003). The truth about stories: A Native narrative. Toronto, ON: Anansi. 
Volume 29, 2019

http://journals.sfu.ca/cjsdw

Klein, J. H., Connell, N. A. D., \& Meyer, E.. (2007). Operational research practice as storytelling. The Journal of the Operational Research Society, 58(12), 1535-1542.

http://www.jstor.org/stable/4622850

Koch, T. (1998). Story telling: Is it really research? Journal of Advanced Nursing, 28(6), 1182-1190.

Lave, J., \& Wenger, E. (1991). Situated learning: Legitimate peripheral participation. Cambridge, UK: Cambridge University Press.

Lupton, D. (2014). "Feeling better connected": Academics' use of social media. News and Media Research Centre, University of Canberra. Retrieved from https://www.canberra.edu.au/about$\underline{\mathrm{uc} / \text { faculties/arts-design/attachments } 2 / \mathrm{pdf} / \mathrm{n} \text {-and-mrc/Feeling-Better-Connected-report- }}$ final.pdf

Mewburn, I., \& Thompson, P. (2013). Why do academics blog? An analysis of audiences, purposes, and challenges. Studies in Higher Education, 38(8), 1105-1119.

https://doi.org/10.1080/03075079.2013.835624

Mewburn, I., \& Thompson, P. (2017). Toward an academic self? Blogging during the doctorate. In The Digital Academic: Critical Perspectives on Digital Technologies in Higher Education edited by, D. Lupton, I. Mewburn, and P. Thompson. Abdington: Routledge.

Mitchell, K. M. (2017a). Academic voice: On feminism, presence, and objectivity in writing. Nursing Inquiry, 24(4), e12200. https://doi.org/10.1111/nin.12200

Mitchell, K. M. (2017b, October 8). Do Academics Devalue Writing? AcademicsWrite. https://academicswrite.ca/2017/10/08/do-academics-devalue-writing/

Mitchell, K. M. (2017c, December 1). Is Social Media the Creation of a Never-Ending Research Story? AcademicsWrite. https://academicswrite.ca/2017/12/01/is-social-media-the-creation-of-anever-ending-research-story/

Richardson, L. (2002). Writing sociology. Culture Studies: Critical Methodologies, 2(3), 414-422.

Richardson, L., \& Lockridge, E. (1998). Fiction and ethnography: A conversation. Qualitative Inquiry, $4(3), 328-336$.

Richardson, L., \& St. Pierre, E. A.. (2005). Writing: A method of inquiry. In Denzin, N. K., and Y. S. Lincoln (Eds.). The Sage Handbook of Qualitative Research (3 $3^{\text {rd }}$ ed.). Thousand Oaks, CA: SAGE.

Rieger, K., \& Schultz, A. S. H. (2014). Exploring arts-based knowledge translation: Sharing research findings through performing the patterns, rehearsing the results, staging the synthesis. Worldviews on Evidenced-Based Nursing, 11(2), 133-139. http://dx.doi.org/10.1111/wvn.12031 
Volume 29, 2019

http://journals.sfu.ca/cjsdw

Rieger, K. L., West, C. H., Kenny, A., Chooniedass, R., Demczuk, L., Mitchell, K. M., Chateau, J., \& Scott, S. D. (2018). Digital storytelling as a method in health research: A systematic review protocol. BMC Systematic Reviews, 41. http://dx.doi.org/10.1186/s13643-018-0704-y

Rolls, K., Hansen, M., Jackson, D., \& Elliott, D. (2016). How health care professionals use social media to create virtual communities: An integrative review. Journal of Medical Internet Research, 18(6), e166. http://dx.doi.org/10.2196/jmir.5312

Ryan, M. M., Walker, M., Scaia, M., \& Smith, V. (2013). (un)Disciplining the nurse writer: Doctoral nursing students' perspective on writing capacity. Nursing Inquiry, 21(4), 294-300. http://dx.doi.org/10.1111/nin.12045

Salter, K. L., \& Kothari, A. (2016). Knowledge "translation" as social learning: Negotiating the uptake of research-based knowledge in practice. BMC Medical Education, 16, 76 http://dx.doi.org/10.1186/s12909-016-0585-5

Sandelowski, M. (1991). Telling stories: Narrative approaches to qualitative research. IMAGE: Journal of Nursing Scholarship, 23(3), 161-166.

Saunders, M. E., Duffy, M. A., Heard, S. B., Kosmala, M., Leather, S. R., McGlynn, T. P., Ollerton, J., \& Parachnowitsch, A. L. (2017). Bringing ecology blogging into the scientific fold: Measuring reach and impact of science community blogs. Royal Society of Open Science 4, 170957. http://dx.doi.org/10.1098/rsos.170957

Stewart, B. (2015). Open to influence: What counts as academic influence in scholarly networked Twitter participation. Learning, Media, and Technology, 40(3), 287-309. http://dx.doi.org/10.1080/17439884.2015.1015547

Stewart, B. (2016). Collapsed publics: Orality, literacy, and vulnerability in academic Twitter. Journal of Applied Social Theory, 1(1), 61-86. http://socialtheoryapplied.com/journal/jast/article/view/33/18

Stewart, B. (2017). Academic Twitter and academic capital : Collapsing orality and literacy in scholarly publics. In D. Lupton, I. Mewburn, and P. Thompson (Eds.). The Digital Academic: Critical Perspectives on Digital Technologies in Higher Education. Abdington, UK: Routledge.

Thoma, B., Murray, H., Huang, S. Y. M., Milne, W. K., Martin, L. J., Bond, C. M., Mohindra R. ... Chan, T. M. (2017). The impact of social media promotion with infographics and podcasts on research dissemination and readership. Canadian Journal of Emergency Medicine. http://dx.doi.org/10.1017/cem.2017.394 
Volume 29, 2019

http://journals.sfu.ca/cjsdw

Thompson, P. (2016). Text work/identity work online: Writing for social media. In C. Sugrue, and S. Mertkan (Eds.). Publishing and the academic world: Passion, purpose, and possible futures. Abdington, UK: Routledge.

Tierney, W. G. (2002). Get real: Representing reality. International Journal of Qualitative Studies in Education, 15(4), 385-398. http://dx.doi.org/10.1080/09518390210145444

Tusting, K. (2005). Language and power in communities of practice. In D. Barton and K. Tusting (Eds.). Beyond communities of practice: Language, power and social context. (pp. 36-54). Cambridge, UK: Cambridge University Press.

Van De Ven, A. H., \& Johnson, P. E. (2006). Knowledge for theory and practice. The Academy of Management Review, 31(4), 802-821. http://www.jstor.org/stable/20159252

Veletsianos, G., \& Kimmons, R. (2011). Networked participatory scholarship: Emergent technocultural pressures toward open and digital scholarship in online networks. Computers and Education, 58, 766-774. http://dx.doi.org/10.1016/j.compedu.2011.10.001

Vickers, M. H. (2010). The creation of fiction to share other truths and different viewpoints : A creative journey and an interpretive process. Qualitative Inquiry, 16(7), 556-565. http://dx.doi.org/10.1177/1077800410371922

Ward, M-H., \& West, S. H. (2008). Blogging the PhD candidature: Revealing the pedagogy. International Journal of Emerging Technologies and Society, 6(1), 60-71.

Woods, A., Cashin, A., \& Stockhausen, L. (2016). Communities of practice and the construction of the professional identities of nurse educators: A review of the literature. Nurse Education Today, 37, 164-169. http://dx.doi.org/10.1016/j.nedt.2015.12.004

Wenger, E. (1998). Communities of practice: Learning, meaning, and identity. Cambridge, UK: Cambridge University Press.

Wieringa, S., \& Greenhalgh, T. (2015). 10 years of mindlines: A systematic review and commentary. Implementation Science, 10, 45 http://dx.doi.org/10.1186/s13012-015-0229-x 